\title{
The Cretan Mesolithic in context: new data from Livari Skiadi (SE Crete)
}

\author{
Tristan Carter ${ }^{1}$, Danica D. Mihailović ${ }^{2}$, Yiannis Papadatos ${ }^{3}$ and Chrysa Sofianou 4 \\ 1 McMaster University, Department of Anthropology, CA \\ stringy@mcmaster.ca 1 \\ 2 University of Belgrade, Department of Archaeology, RS \\ 3 National and Kapodistrian University of Athens, Department of History and Archaeology, GR \\ 4 Hellenic Ministry of Culture and Sports, Ephorate of Antiquities of Lasithi, GR
}

\begin{abstract}
Investigations at Livari (south-eastern Crete) produced a small Mesolithic chipped stone assemblage, whose techno-typological characteristics situate it within an 'early Holocene Aegean island lithic tradition' (9000-7000 cal BC). The material provides antecedent characteristics for the lithics of Crete's founder Neolithic population at Knossos (c. 7000-6500/6400 cal BC). The idiosyncrasies of the Knossian material can be viewed as a hybrid lithic tradition that emerged from interaction between migrant Anatolian farmers and indigenous hunter-gatherers. Small quantities of Melian obsidian at Livari attest to early Holocene maritime insular networks, knowledge of which likely enabled the first farmers' successful voyage to Crete.
\end{abstract}

IZVLEČEK - Raziskave na najdišču Livari (na jugovzhodu Krete) so pokazale navzočnost drobnega mezolitskega kamnitega inventarja, katerega tehnološke in tipološke značilnosti ga postavljajo $v$ okvir 'zgodnje holocenske egejske tradicije kamnitih artefaktov' (9000-7000 cal BC). Ta material predstavlja predhodnike tipov kamnitih orodij, ki so značilna za kretsko ustanoviteljsko neolitsko populacijo v Knossosu (ok. 7000-6500/6400 cal BC). Značilnosti materiala iz Knossosa kažejo na hibridne tradicije $v$ tipologiji kamnitih artefaktov, ki so se pojavile kot posledica interakcije med migranti - poljedelci iz Anatolije in domorodnimi lovci in nabiralci. Manǰsa količina obsidiana iz Melosa na najdišču Livari pa kaže na zgodnje holocensko morsko omrežje, ki je potekalo med otoki, kar je omogočalo prvim poljedelcem, da so pridobili znanje za uspešno plovbo do Krete.

KEY WORDS - Greece; Aegean Islands; Mesolithic; Neolithisation; lithics; Knossos

\section{Introduction}

Until recently, the received wisdom was that Crete (Fig. 1), the fifth largest island in the Mediterranean, had remained unoccupied until the founding of the Initial Neolithic (hereafter 'IN') village at Knossos by migrant Anatolian farmers around $7000 \mathrm{BC}$ (Broodbank, Strasser 1991; Evans 1994; King et al. 2008). Crete was thus something of an anomaly, given that later Palaeolithic populations were known on the islands of Corsardinia (22 000-18 500 BC), Cyprus (11th millennium BC), and Sicily some 30000 years ago (Broodbank 2006.205-209; dates hereafter given as cal BC). Even in the Aegean, pre-Neolithic sites had begun to be reported by this time on a number of significantly smaller islands, including Ikaria, Kythnos, Melos, and Youra (Broodbank 2006.204-205, 211; Sampson et al. 2010; 2012), while a DNA study argued that some modern Cretans embodied traces of a local Middle Pleistocene population (Martinez et al. 2007). In 2008, evidence for Palaeolithic and Mesolithic activity was finally discovered on Crete's

1 Correspondence to: Tristan Carter, Department of Anthropology, CNH 524, McMaster University, 1280 Main Street West, Hamilton, Ontario, L8S 4L9. Email: stringy@mcmaster.ca 
south-west coast, the former $\mathrm{da}$ ted to at least $110000-130000$ BP (Strasser et al. 2010; 2011).

These new data force us to confront a number of questions. Firstly, do they imply Crete's continual occupation from the Middle Pleistocene, or are these traces of intermittent visitations and/ or failed colonisations? Secondly, when the migrant farmers arrived at Knossos, did they land on unoccupied territory, or were they confronted by an indigenous hunter-gatherer population? If the latter, what implications does this have for our understanding of early Knossos and the origins and nature of Neolithic society on Crete? Does the material cul-

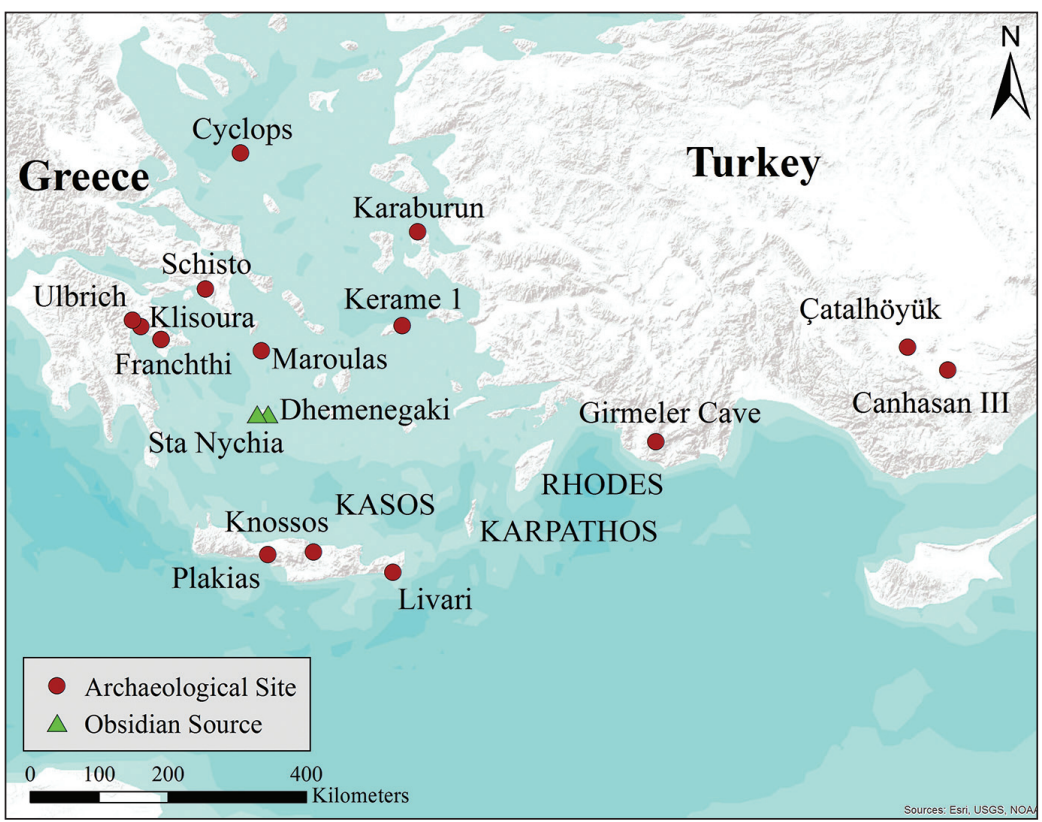

Fig. 1. Location of main sites and regions mentioned in the text. ture of IN Knossos attest to interactions between the two groups? Thirdly, in coming to Crete, did these Anatolian seafaring farmer-herders paddle into unknown waters, or were they drawing on ancient maritime knowledge, taking advantage of pre-existing routes and interaction networks, with the settlement at Knossos being the result of prior reconnaissance trips (cf. Strasser 1996.327-328)?

This paper attempts to answer these questions through detailing a new Mesolithic chipped stone assemblage from Livari Skiadi in south-eastern Crete. The assemblage is contrasted with broadly contemporary data sets from the Eastern Mediterranean to see if Cretan practices can be located within larger regional traditions. We then reflect on the material's relationship to that from IN Knossos. Our work thus employs lithic technology as a means of contributing to debates on the nature and dynamics involved in the Neolithisation of the larger region $(c f$. Cauvin 2000; Kotsakis 2003; Perlès 2001; Pinhasi et al. 2005).

\section{Livari Skiadi}

The existence of a Cretan Mesolithic was first claimed via the publication of stone tools from surveys at Moni Kapsa and Plakias on the southern coast (Galanidou 2011.224; Strasser et al. 2010); one of the latter sites, Damnoni, having since been excavated (Strasser et al. 2015). Here we report on Livari Skiadi (hereafter Livari), the second Mesolithic site to have been dug on Crete (Fig. 1).

Situated on Crete's south-eastern littoral, Livari today comprises a small and relatively flat coastal plain enclosed by low steep hills to the north. It is cut by several streams, two in quite deep gorges, while a spring provides a year-round water supply (Fig. 2). Aeolian and sea erosion has largely removed the Holocene soil deposits, exposing large areas of the natural bedrock, a Miocene conglomerate consisting of limestone, dolomite and chert (Brandl 2010). In 2008-2010 the Greek Archaeological Service excavated a small Early-Late Bronze Age cemetery at Skiadi, $50 \mathrm{~m}$ from the modern seashore (Papadatos, Sofianou 2015). While the work's focus was the $3^{\text {rd }}$ $2^{\text {nd }}$ millennia $\mathrm{BC}$ burials in a tholos, rock shelter and 'house tomb' (Fig. 3), it subsequently became apparent that there were also traces of Mesolithic occupation. This is not an insignificant claim, and as such requires substantiating.

\section{The evidence for Mesolithic Livari}

The evidential basis of Livari's Mesolithic occupation is comprised primarily of chipped stone artefacts (Figs. 4-6). The material derives from thin remnant Holocene soil deposits that were protected from erosion by the rock shelter and Bronze Age tombs (suggesting that most soil was lost after the $2^{\text {nd }}$ millennium BC). It is important to state that the excavators found no stratigraphic distinctions between the material we claim to be Mesolithic and Bronze Age, i.e. these were mixed deposits due to the later activities associated with the $3^{\text {rd }} 2^{\text {nd }}$ millennium cemetery. The total lithic assemblage from the excava- 


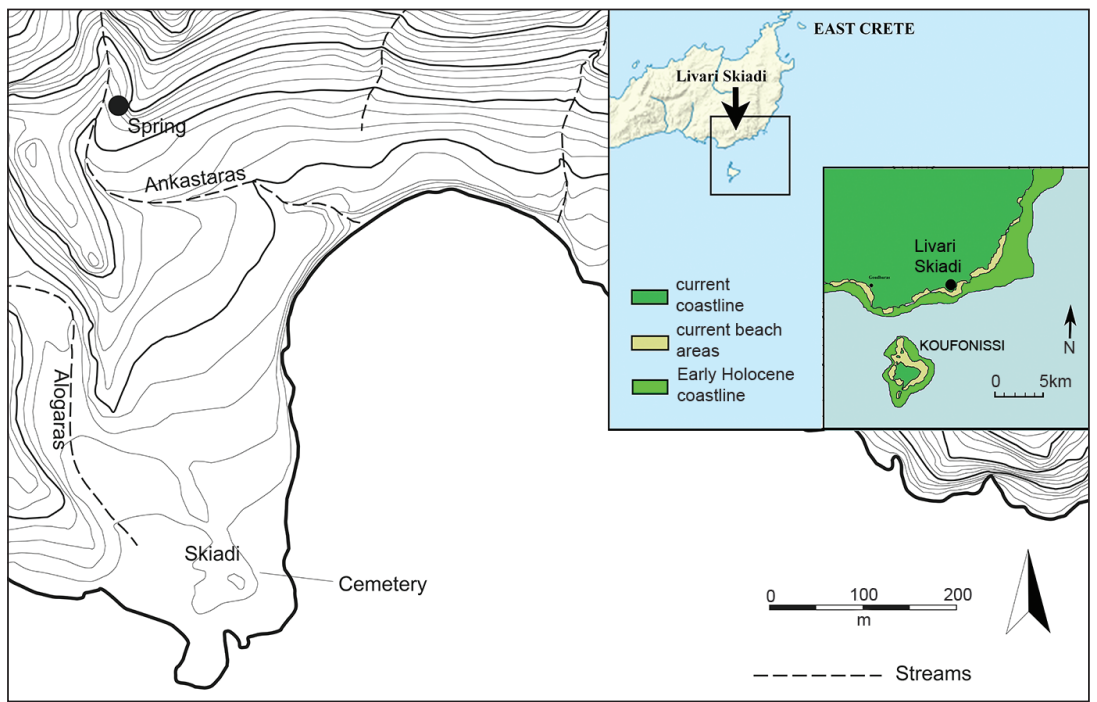

Fig. 2. Map of the Livari plain and early Holocene coastline reconstruction.

sent bulbar scars (Carter 2015.114-115; see also Tixier 1984). Their dihedral platforms, lack of lip and overhang attests to the use of a copper-tipped flaking tool $(\mathrm{Pe}$ legrin 2012.485-490). The other three pressure blades were made of chert, one greyish-blue, the other two tan in colour (Fig. 4.CS10-C11).

The recovery of obsidian pressure blades from a Cretan Bronze Age cemetery is entirely in keeping with the islanders' funerary traditions of the $3^{\text {rd }}-2^{\text {nd }}$ millennia cal BC.

tion comprised 469 pieces, of which 251 are identified as Mesolithic. This claim is based on an integrated four-fold approach that considers the role and nature of chipped stone tools in Cretan Bronze Age burial practices/contexts, the techno-typological characteristics of the assemblage, raw material selection, and intra-site artefact distribution. A further posited 20 Mesolithic artefacts were subsequently collected from the site's surface within a $20 \mathrm{~m}$ radius of the excavation area in 2014.

The Livari chipped stone assemblage is made up of two techno-typologically distinct components. The first comprises obsidian pressure-flaked blades of Bronze Age date (Fig. 4). The second component of the Livari material consists of a microlithic flakebased tradition, most of which were produced using local raw materials (Figs. 5-6); this material, we argue, is Mesolithic.

\section{The Bronze Age assemblage}

Just under half of the Livari chipped stone $(n=218 / 469)$ comprises fragmentary prismatic blades (Fig. 4). Most of these implements are made of obsidian $(\mathrm{n}=215 / 218,99 \%)$, a raw material that is exotic to Crete, the closest sources being located in the Aegean islands (Carter 2009). These fine, razor-sharp blades were pressure flaked, as evidenced by their parallel margins and dorsal ridges, even longitudinal thickness, diffuse bulbs of 'percussion', and small or ab-
This Livari material has numerous parallels. Indeed, Carter (1998;1999; 2010) has studied/published over 20 of these data sets from eastern and central Crete. These obsidian-dominated assemblages are highly structured, lacking cores or production debris. The fragmentary state of these implements is likely due to their post-depositional breakage, rather than deliberate fragmentation. The blades' freshness and almost complete lack of use-wear further suggest that they were produced specifically for funerary consumption.

While Crete is known to have small deposits of knappable cherts and other siliceous materials throughout the island (cf. Blitzer 2004.511; Brandl 2010; Carter 2007.685-688; inter alia), tools of these raw materials are rarely documented in these burial assemblages. Moreover, such local resources tended to have been ignored by Cretan/southern Aegean Bronze Age populations, with obsidian being the

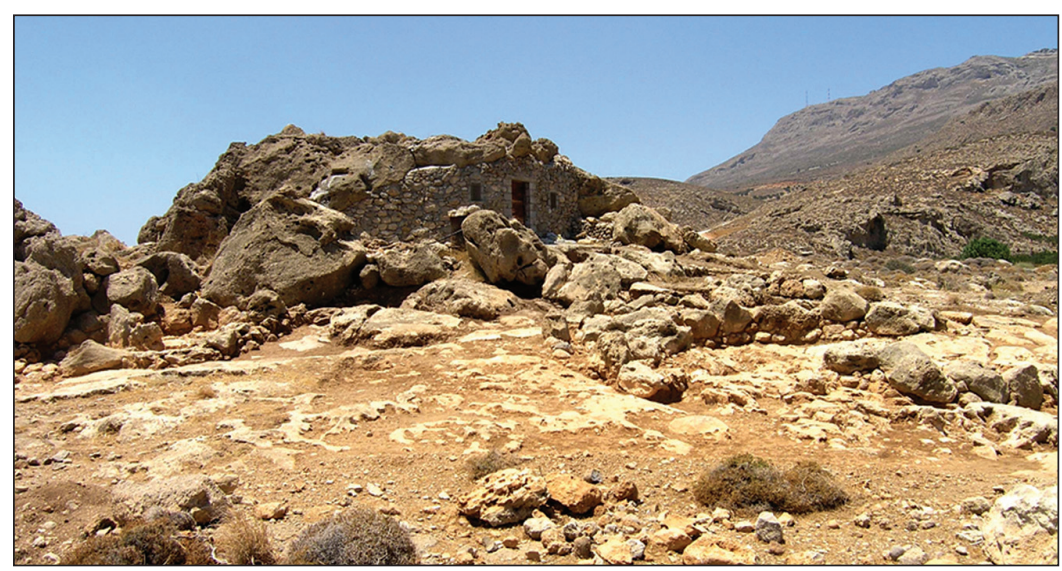

Fig. 3. View of Livari rock shelter from the south-west. Tholos tomb to the right, 'house tomb' to the left. 
raw material of choice for both domestic and funerary products (Carter 2009.202-204).

\section{The Mesolithic assemblage}

The remainder of the Livari assemblage is microlithic in character (few pieces $>2.5 \mathrm{~cm}$ ), dominated by local chert and radiolarite (Brandl 2010), and derived from flake (dominant, $\mathrm{n}=220,88 \%$ ) and bladelet traditions $(\mathrm{n}=31,12 \%)$, with the blanks percussion-knapped from pebble cores (Figs. 5-6). Such material is completely unknown from the numerous Cretan Bronze Age assemblages we have studied (Carter 2015, for references). Nor are the artefacts believed to be Neolithic, as Cretan assemblages of this date are almost exclusively obsidian-and bladebased (e.g., Christopoulou 1989); only at IN Knossos is there a significant component of flake-tools and bladelets, although here, too, obsidian prevails (70\%; Conolly 2008). The relationship between the Livari and IN Knossos assemblages is discussed below.

The lithics were recovered carefully, with all soil sieved through a 300 micron-mesh. While the chipped stone all seems to derive from secondary contexts intermixed with Bronze Age burial material (no stratigraphic distinction was noted), we highlight the fact that the distribution of the chert percussion flake/ bladelet material does not mirror that of the obsidian pressure-blades (Tab. 1). We believe strongly that this contextual distinction is due to their chronological differences. For instance, the deposition of burials and grave goods ( $28 \%$ of the obsidian blades) deep in the rock shelter is a well-attested practice in Bronze Age Crete (Branigan 1988.153154), yet such a dark, cramped space makes little sense for Mesolithic activity, thus explaining why only $3 \%$ of the chert artefacts came from here.

For the flake tradition using local raw materials, we have the entire reduction sequence, with nuclei, cortical debris, and tools. The cores were reduced multi-directionally (Fig. 6.1), although there are a few unipolar cores and three (opposed platform) pieces esquillèes, a few being related to on-site percussion bladelet production $(12 \%, n=31)$, with cores, platform rejuvenation tablets, and end-products (Fig. 6.2-3).

A high proportion of the percussion flake and bladelet tradition material is modified $(\mathrm{n}=110,44 \%$; Fig. 6.4-16, 18-22; Tab. 2); this is again quite different to Cretan Bronze Age assemblages, which typically have $<10 \%$ retouched pieces (Carter 2015. 116). Most have simple linear modification (Tab. 2), followed by 'spines', i.e. pointed tools used as borer/ perforators or drills (Fig. 6.8-11), notches, denticulates, composite tools, scrapers (Fig. 6.21-22), blanks with convergent retouch (broader tips than 'spines' (Fig. 6.6-7)), geometrics (Fig. 6.18-20), and backed pieces. There were two burin spalls, but no burins per se. Inverse retouch is common, noted on a third of the modified pieces ( $n=34,33 \%)$; this is a characteristically Mesolithic mode of modification (cf. Perlès 1990.Doc. II.11), quite distinct from Neolithic or Bronze Age tool-making traditions. Many of the artefacts also display macroscopic use-wear, whether retouched or otherwise.
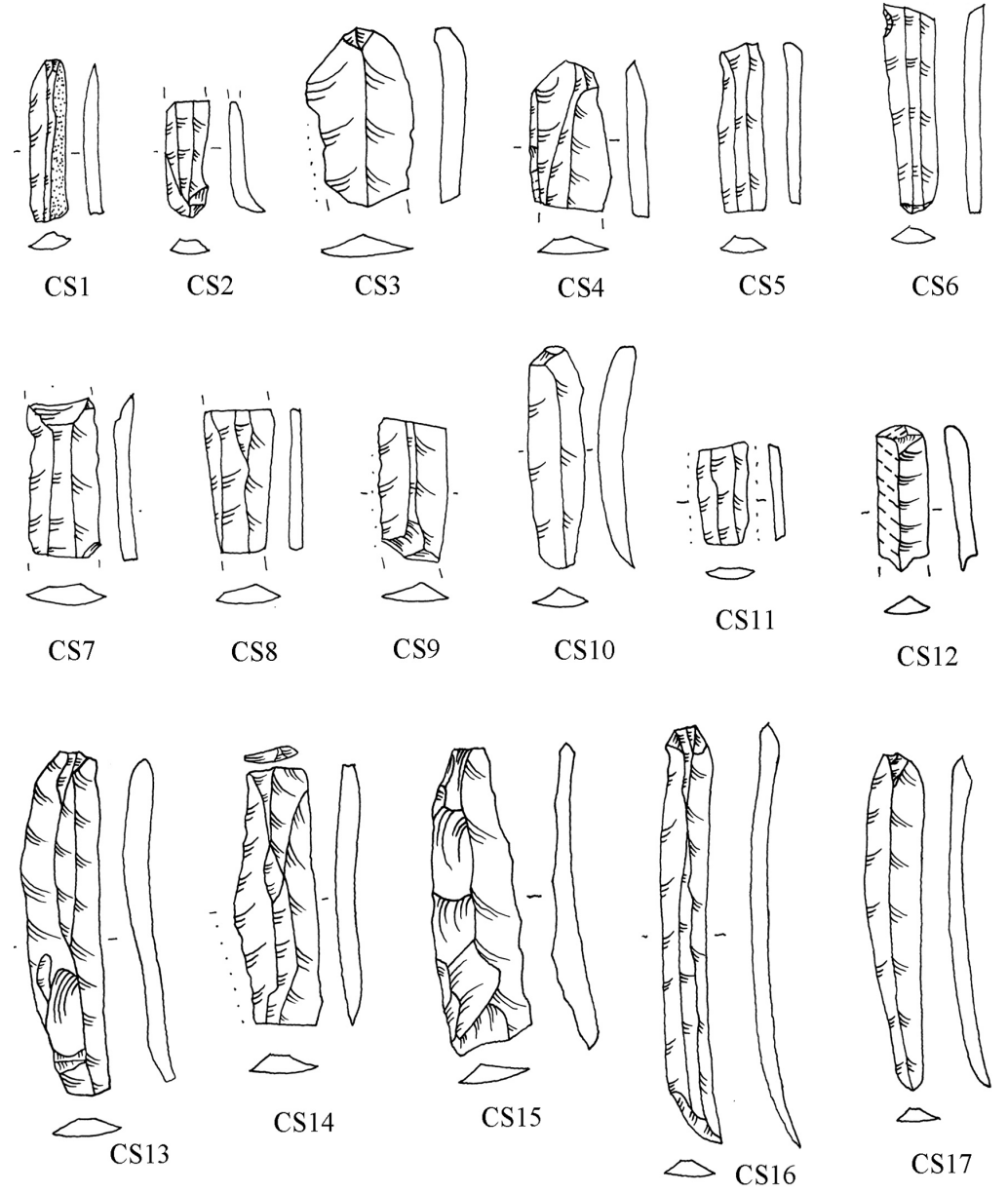

Fig. 4. Bronze Age pressure blades from Livari made of obsidian and chert (CS 10-11). 


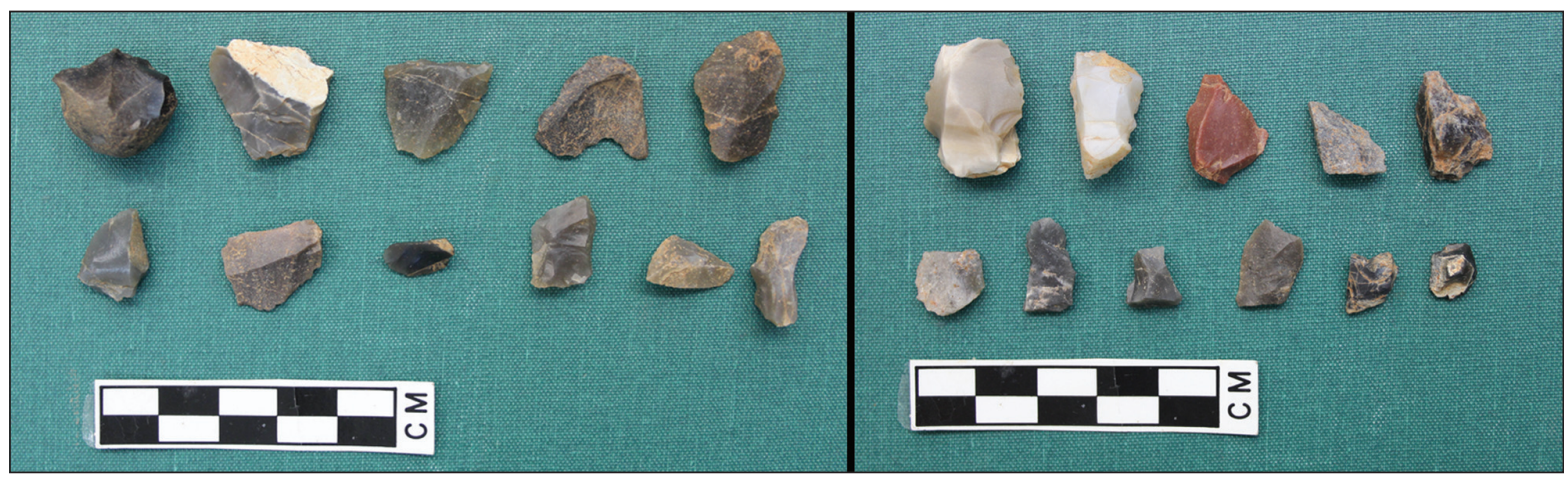

Fig. 5. Mesolithic artefacts from Livari made of local cherts.

While our claim for early Holocene activity is constituted primarily on the quintessentially Mesolithic character of its chipped stone, Livari also fits the Aegean Mesolithic site-location model forwarded by Runnels (2009.60-62) at the "intersection of woodland and aquatic habitats". The site is located in front of a rock shelter, offering protection from the strong north winds, with a nearby spring and small caves in the gorge, with the early Holocene coastline approx. $1.5 \mathrm{~km}$ to the south (Fig. 2). This coastal wetland plain would have provided a perennial water supply, and a rich array of animals, plants, and marine resources for hunter-fisher-gatherer subsistence, a setting directly comparable to the "foraging coastscapes" (Broodbank 2006.211) enjoyed by the welldocumented Mesolithic populations of the southern Argolid (Runnels 2009).

\section{Dating the Livari material and its relationship to early Holocene traditions of the Eastern Me- diterranean}

Given the mixed nature of the Livari deposits, the chert/flake-dominated assemblage can be dated only through reference to comparanda from elsewhere. Perhaps unsurprisingly, the closest parallels come from the Plakias sites $180 \mathrm{~km}$ to the west (Fig. 1), which are similarly flake-based and microlithic, with 'spines', denticulates, geometrics, notched, and backed pieces (Strasser et al. 2010.163-171, Tab. 2). Preliminary reports of the material from stratified Mesolithic deposits at Damnoni details a directly comparable assemblage to the Livari chert (Strasser et al. 2015.278, Figs. 79), an impression that is further strengthened through Danica Mihailovićs first-hand study of both data sets (Fig. 7). With absolute dates yet to be published from Damnoni, we need to consider parallels from overseas excavated assemblages in order to offer some thoughts on Livari's chronolo- gy, with that from the mainland Franchthi Cave being particularly informative (Fig. 1).

The Livari material has much to compare with the Lower-Final Mesolithic assemblages from Franchthi's lithic Phases VII-IX (Fig. 6; Tab. 3) that span 85007000 BC (Perlès 2001.Tab. 2.1). These assemblages are similarly microlithic and dominated by flakes (95\%) struck from small pebble cores, with notches/ denticulates being the most common tools, followed by flakes with simple linear retouch, scrapers, backed pieces, and geometrics inter alia (Perlès 1990.2393, Figs. 5-8, 13-19, 21-22), although Livari has a significantly higher proportion of 'spines' (Fig. 6). The Livari material also includes proportionally more bladelets than at Franchthi VII-IX (12\%; v. 4-5\%), and instances of inverse retouch (33\%; v. 17\%); these are both features more characteristic of Final Palaeolithic assemblages (Perlès 1987), i.e. the Livari material is potentially of earlier Mesolithic date (Phase VII in Franchthi terms, second half of the $9^{\text {th }}$ millennium BC).

While strong links can be established with the Franchthi lithics, Livari is ultimately better viewed as part of the 'early Holocene Aegean Island lithic tradition' (Figs. 1 and 8; Tab. 3). This tradition was first defined by Adamantios Sampson et alii (2010.6869) through reference to material from Maroulas on Kythnos in the Cyclades (early-mid $9^{\text {th }}$ millennium $\mathrm{BC}$ ), the Cave of the Cyclops on Youra in the Spora-

\begin{tabular}{|lcccc|}
\hline Context & $\begin{array}{c}\text { Pressure } \\
\text { Blade \# }\end{array}$ & $\begin{array}{c}\text { Pressure } \\
\text { Blade \% }\end{array}$ & $\begin{array}{c}\text { Flake/ } \\
\text { Bladelet \# }\end{array}$ & $\begin{array}{c}\text { Flake/ } \\
\text { Bladet \% }\end{array}$ \\
\hline Rockshelter & 60 & 28 & 8 & 3 \\
\hline House Tomb & 51 & 23 & 40 & 15 \\
\hline Tholos Tomb & 29 & 13 & 143 & 55 \\
\hline Around the Tholos & 78 & 36 & 68 & 24 \\
\hline
\end{tabular}

Tab. 1. Distribution of chipped stone at Livari by context, raw material and technology. 
1

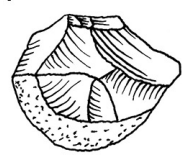

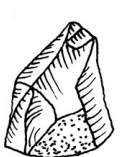
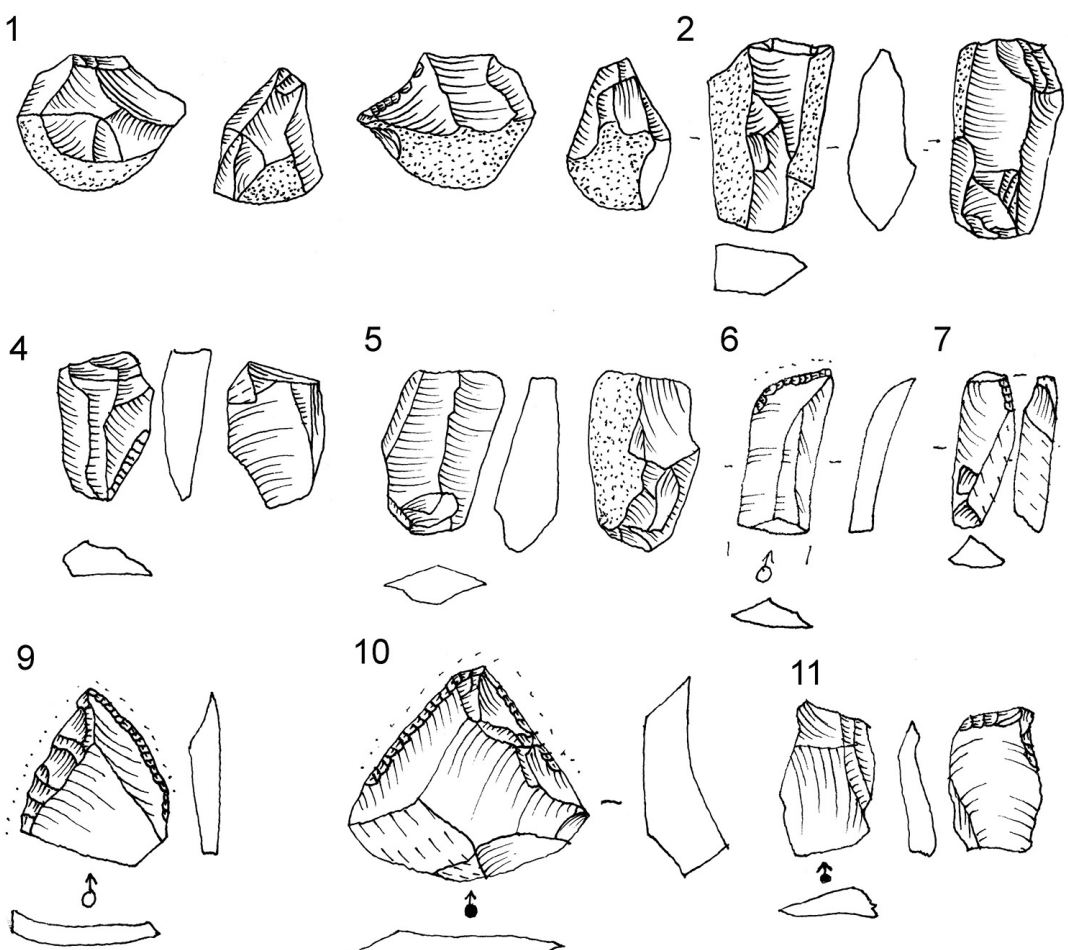

10

5
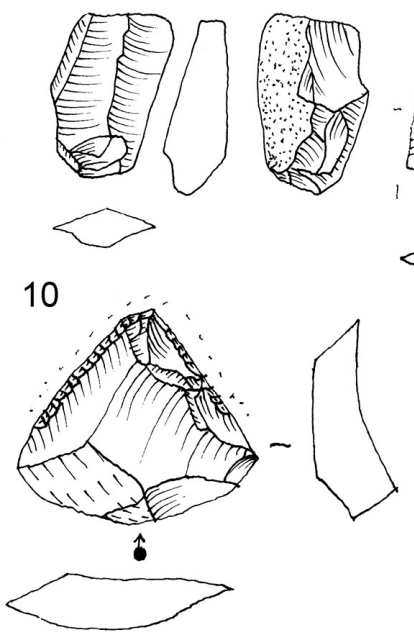

6

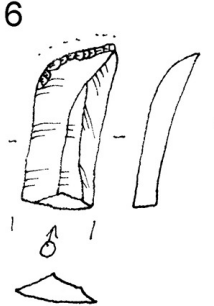

11

7
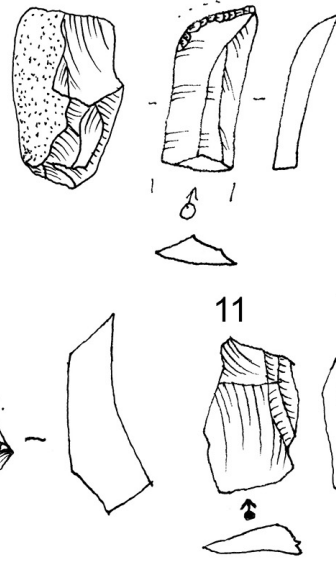

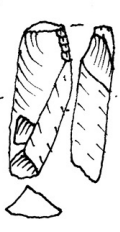

8

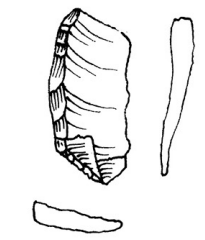

12

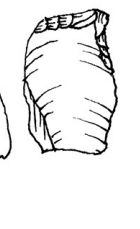

3

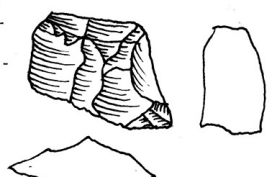

$>$

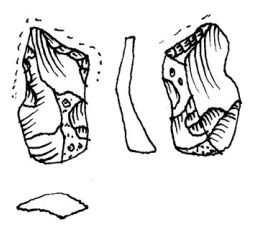

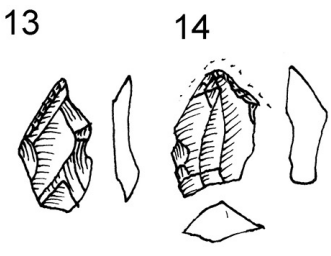

$15^{*}$

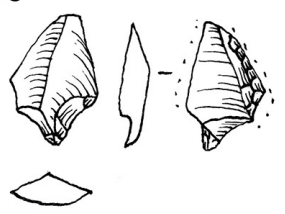

16

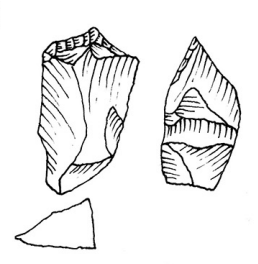

17

18
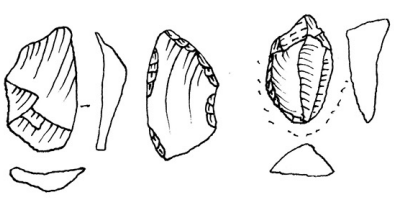

$19^{*}$

20

21

22 *

$23^{*}$
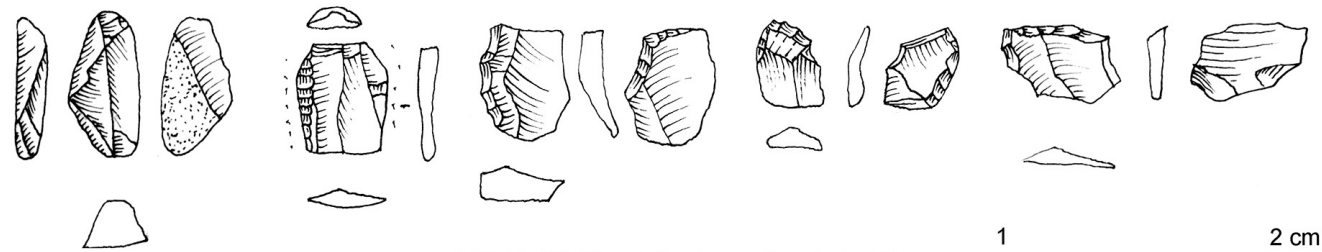

*15,19,22,23 artefacts made of obsidian

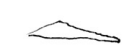

$2 \mathrm{~cm}$

Fig. 6. Mesolithic artefacts from Livari. 1 multidirectional flake core/micro chopper with spine, 2 bladelet core/pièce esquillèe, 3 core rejuvenation flake, 4-5 unidirectional retouched bladelets, 6-7 flakes with convergent retouch, 8-11 'spines', 12-16 retouched flakes, 17 flake, 18-20 geometrics with backed elements, 21-23 short scrapers on flakes (14-17 obsidian, 18-23 survey material).

des (c. 8600-7800 BC), Kerame 1 on Ikaria in the Dodecanese (Sampson 2008; Sampson et al. 2010; 2012), plus Stélida and Roos on Naxos (Carter et al. 2013; 2016; Sampson 2015). These assemblages are also flake-dominated, with denticulates, notches, perforators, scrapers, and backed pieces, but have few opposed platform cores compared to mainland sites ( $\mathrm{n}=3 / 11$ at Livari). The Cyclops Cave aside, these assemblages, Livari included, also have notable quantities of 'spines', a further distinction from the Franchthi material (Fig. 8).
The Livari Mesolithic lithics provide further proof of overseas connections through the presence of four pieces of obsidian $(n=4 / 251,1.6 \%)$ which were characterised by energy- dispersive x-ray fluorescence spectroscopy as being products of the Sta Nychia source on Melos (Fig. 1), 235km away in the Cyclades (Carter 2016). These obsidian artefacts can be distinguished easily from the Bronze Age pressure blades on the basis of their technology, form, and size, comprising a retouched bladelet, a 'spine' on a blade-like flake, a retouched part-cortical flake, and 


\begin{tabular}{|c|c|c|c|c|c|c|c|c|c|}
\hline CHERT & Linear & 'Spine' & Notch & Scraper & Denticulate & Composite & Convergent & Backed & Geometric \\
\hline Flake & 18 & 12 & 12 & 8 & 8 & 10 & 6 & & 3 \\
\hline Blade-like flake & 4 & 8 & 1 & 1 & 2 & & & 2 & \\
\hline Bladelet & 1 & 1 & 1 & & 1 & 1 & & 2 & \\
\hline Core & & & & 3 & 1 & & & & \\
\hline Core-tablet & & & & 1 & & & & & \\
\hline \multicolumn{10}{|l|}{$\overline{\overline{\text { OBSIDIAN }}}$} \\
\hline Flake & 2 & & & & & & & & \\
\hline Bladelet & & 1 & & & & & & & \\
\hline TOTAL $(n=110)$ & $25(23 \%)$ & $22(20 \%)$ & 14 (13\%) & $13(12 \%)$ & 12 (11\%) & 11 (10\%) & $6(5 \%)$ & $4(4 \%)$ & $3(3 \%)$ \\
\hline
\end{tabular}

Tab. 2. Modified tools from the Livari excavation by raw material and blank type.

a denticulated flake (Fig. 6.14- 17). While we believe this to be the earliest Melian obsidian on Crete, the exploitation of these raw materials at distance has an earlier heritage, having been procured by populations from continental Greece during the $11^{\text {th }}$ millennium BC Upper Palaeolithic (Renfrew, Aspinall 1990). While mainland hunter-gatherers continued to exploit this material during the early Holocene $\left(9^{\text {th }}-8^{\text {th }}\right.$ millennia BC), the primary Mesolithic consumers of Melian obsidian were insular huntergatherers with ready waterway access to the Cyclades (Fig. 1); linear distance from source cannot alone explain the distribution patterns (Tab. 4). The tiny quantities of obsidian attested at the Franchthi Cave and Livari suggests that the inhabitants of the mainland and southern Crete likely relied on intermediary exchange to access these Melian resources (Carter 2016.18). The obsidian artefacts at all of these Mesolithic sites were made in the same way as tools flaked from local materials, although at Livari there is no evidence for obsidian being worked on-site.

Turning our attention eastwards and southwards, how do the Mesolithic assemblages of the Aegean islands relate to contemporary material from Anatolia, Cyprus, the Levant, or North Africa? Can one document early Holocene supra-regional lithic traditions, i.e. common technical practices that developed through close social interaction, such as the establishment of exchange and kin partnerships ( $c f$. Carter et al. 2013)? More specifically, if we can define hunter-gatherer networks linking Cretan populations with their eastern contemporaries, then we conceivably have evidence for the bodies of knowledge through which outsider migrant farmers came to know of particular Aegean destinations and the routes with which to reach them.

If we focus on well-dated excavated assemblages, then the Aegean material bears little resemblance to most Anatolian, Levantine and North African traditions of the $9^{\text {th }}-8^{\text {th }}$ millennia BC (Fig. 9). Huntergatherer (Epi-Palaeolithic) assemblages of Mediterranean and central Anatolia are bladelet based with geometrics (Kartal 2009; Baird et al. 2012.194195), while the early farmers of Pre-Pottery Neolithic (PPN) south-eastern Turkey and the Levant had skilled blade industries (Shea 2013.213-260). In turn, the lithic traditions of the Western desert and Nile Valley (Quarunian) are bladelet/ geometric in character (Midant-Reynes 2000.72-74, 77-82), while those of the Typical Capsian assemblages of North

\begin{tabular}{|c|c|c|c|c|c|c|c|c|c|c|c|c|}
\hline Site & Date & Flake & Blade(let) & Retouch & Linear & 'Spine' & $\begin{array}{l}\text { Notch/ } \\
\text { Dent. }\end{array}$ & $\begin{array}{c}\text { Compo- } \\
\text { site }\end{array}$ & Scraper & Backed & Geom. & Other \\
\hline Livari & ?M & $88 \%$ & $12 \%$ & $44 \%$ & $23 \%$ & $20 \%$ & $24 \%$ & $10 \%$ & $12 \%$ & $4 \%$ & $3 \%$ & $6 \%$ \\
\hline Franchthi VI & UP & $91 \%$ & $9 \%$ & n.d. & $9 \%$ & - & $8 \%$ & - & $7 \%$ & $40 \%$ & $28 \%$ & $7 \%$ \\
\hline Franchthi VII & LM & $97 \%$ & $3 \%$ & n.d. & $34 \%$ & $3 \%$ & $33 \%$ & $4 \%$ & $11 \%$ & $8 \%$ & $2 \%$ & $6 \%$ \\
\hline Franchthi VIII & UM & $95 \%$ & $5 \%$ & $7 \%$ & $34 \%$ & $4 \%$ & $41 \%$ & $5 \%$ & $10 \%$ & - & - & $6 \%$ \\
\hline Franchthi IX & FM & n.d. & n.d. & n.d. & $28 \%$ & $3 \%$ & $46 \%$ & $12 \%$ & $3 \%$ & $1 \%$ & $3 \%$ & $2 \%$ \\
\hline Kerame 1 & LM & $97 \%$ & $3 \%$ & n.d. & $22 \%$ & $19 \%$ & $20 \%$ & - & $22 \%$ & $11 \%$ & $1 \%$ & $7 \%$ \\
\hline Maroulas & LM & $97 \%$ & $3 \%$ & $11 \%$ & $19 \%$ & $16 \%$ & $26 \%$ & - & $24 \%$ & $3 \%$ & $4 \%$ & $8 \%$ \\
\hline Cyclops Cave & L/UM & $93 \%$ & $7 \%$ & $25 \%$ & $20 \%$ & $2 \%$ & $11 \%$ & $9 \%$ & $11 \%$ & $2 \%$ & $7 \%$ & $33 \%$ \\
\hline
\end{tabular}

Tab. 3. Comparing basic blank types (relative proportion) and the retouched component of the Livari percussion flake and bladelet assemblage with late Pleistocene-early Holocene material from the mainland and Aegean Islands (UP = Upper Palaeolithic; L/U/FM =Lower/Upper/Final Mesolithic; Dent. $=$ denticulate; Geom. = geometric; data from Perles 1990; Sampson 2008; Sampson et al. 2010; 2012). 
1) $\pi 01 / 4.57$

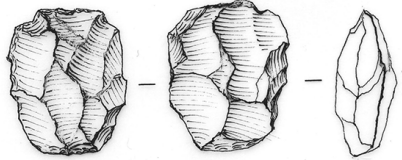

4) $A F 05 / 2.141$

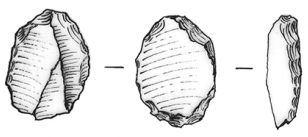

7) $A I 06 / 4.154$

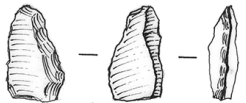

2) $A J 05 / 3.121$

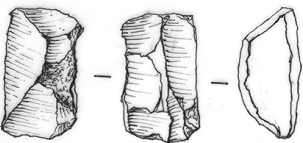

5) $\mathrm{AA06/5.66}$

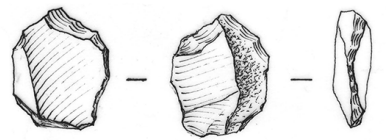

8) $\pi 04 / 1.1$

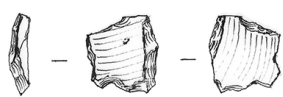

3) $\pi 01 / 4.57$

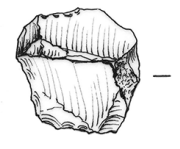

6) $A G 05 / 2.108$

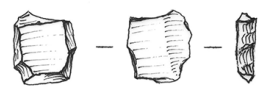

9) AG06/1.169

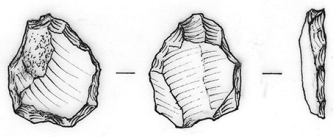

10) $\mathrm{AE} 04 / 2.148$

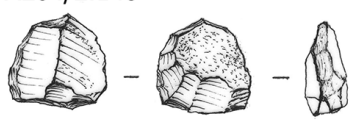

11) $\mathrm{AI06/4.154}$

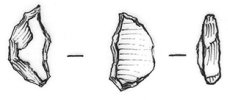

12)AE04/2.148

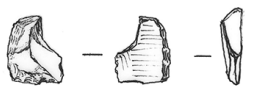

13) $\mathrm{AC06/3.45}$

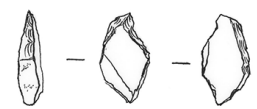

14) $A J 05 / 3.121$

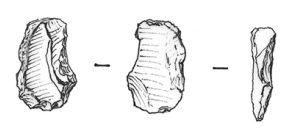

15) $T \pi 01 / 4 . .57$

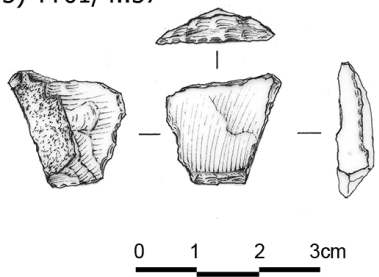

16) $\mathrm{AIO6} / 4.154$

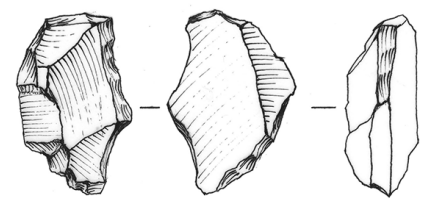

Fig. 7. Mesolithic quartz artefacts from Damnoni. 1 multidirectional flake core, 2 pièce esquillée, 3-5 flakes with linear retouch, 9-10 endscrapers, 11-13 'spines', 14 notch, 15 pseudo-trapeze, 16 denticulate.

Africa are blade/bladelet-based with geometrics (Rahmani 2004.70-75).

One possible connection to the Cretan/Aegean Mesolithic material is Cypriot. While Cyprus of 9000$7000 \mathrm{BC}$ formed part of the PPN world with its fine blade traditions (Knapp 2013.74-119), a survey at Nissi Beach (south-east Cyprus) collected material $(n=2225)$ that allegedly resembles Aegean early Holocene assemblages. The lithics are 'microflake'based (from pebble cores), with scrapers, backed pieces, and spines, the material purportedly representing the tool-kits of foragers who were either occupying the island during the late Epi-Palaeolithic, or early contemporaries of the earliest Cypriot farmers (Kaczanowska, Kozlowski 2014.52-55, Fig. 27). While a tantalising potential link to Mesolithic Aegean populations, knowledge of which may have later been used by migrant farmers venturing westwards from Cyprus (as attested genetically; King et al. 2008), the current evidential basis is insubstantial given the lack of absolute dates.
Finally, there is tantalising evidence for comparable material emerging from archaeological work in south-western and western Anatolia, i.e. the obvious continental landfall en route from Cyprus, and/ or point of departure for anyone paddling to Crete from Anatolia (Kartal 2009.Fig. 15; Horejs et al. 2015.Fig. 15). The excavation of late 9th/ early $8^{\text {th }}$ millennia BC deposits from the Girmeler Cave in SW Turkey (Fig. 1) produced a 'flint' percussion-knapped flake-based assemblage - with some bladelets including multidirectional cores and modified forms such as scrapers and perforators, but no classic microlithic types (Takaoğlu et al. 2014.112-113, Fig. б). The excavators note the materials' distinction from central Anatolian and Antalya region lithic traditions of the period, while also drawing tentative parallels with Aegean Island Mesolithic assemblages (Takaoglu et al. 2014.114). The second assemblage comes from a survey of the Karaburun Peninsula on western Anatolia, opposite the eastern Aegean island of Chios (Fig. 1). The 116 artefacts of 'white patinated flint' were the products of a non- 

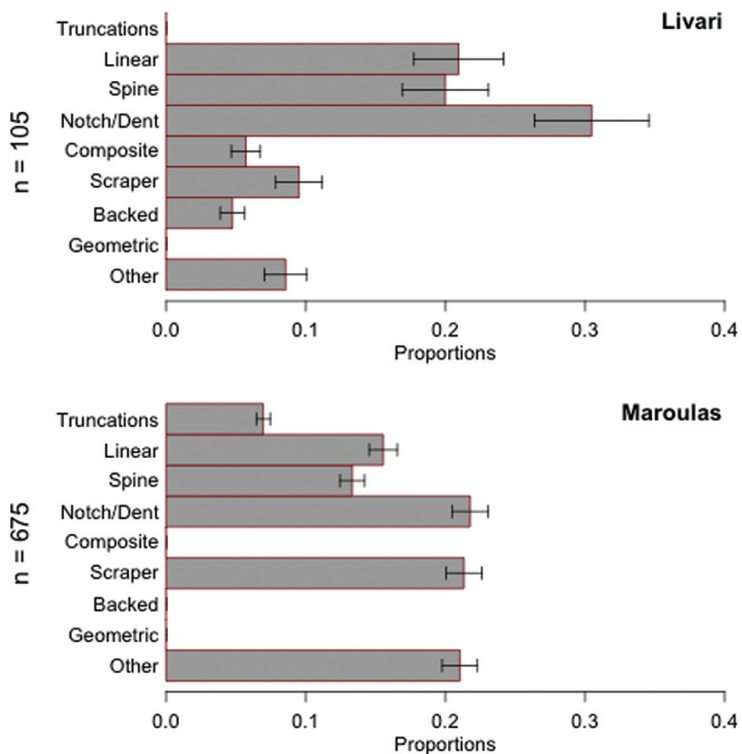

Fig. 8. Composition of lithic assemblages from the main excavated Aegean Mesolithic sites discussed in the text.

standardised flake-based tradition (only three blades recorded), with the few retouched pieces (approx. $10 \%$ ) including scrapers and notches (Cilingiroğlu et al. 2016.3-5, Figs. 4-5). The survey team clearly contrasts this material with the bladelet- and bladebased traditions of the Epipalaeolithic and Pre-Pottery Neolithic Eastern Mediterranean, instead drawing comparisons with Aegean Mesolithic assemblages (Çilingiroğlu et al. 2016.5-6).

\section{The relationship of Crete's indigenous Mesoli- thic traditions to Initial Neolithic Knossos}

So what impact has the new Cretan Mesolithic finds on how we view IN Knossos? Firstly, we need to be clear about what these data do not change. For instance, we still lack solid evidence for an indigenous hunter-gatherer population inhabiting Crete when the migrant farmers arrived around $7000 \mathrm{BC}$. With elements of the Livari and the Plakias region sites finding their best parallels from Franchthi Phase VIII of the earlier $8^{\text {th }}$ millennium BC (Strasser et al. 2010.164 ), there could conceivably be a lacuna in Cretan occupation of at least 500 years until Knossos was founded (Perlès 1990.46-47). Moreover, even if the island was inhabited by local huntergatherers, it does not change the newcomers' impact
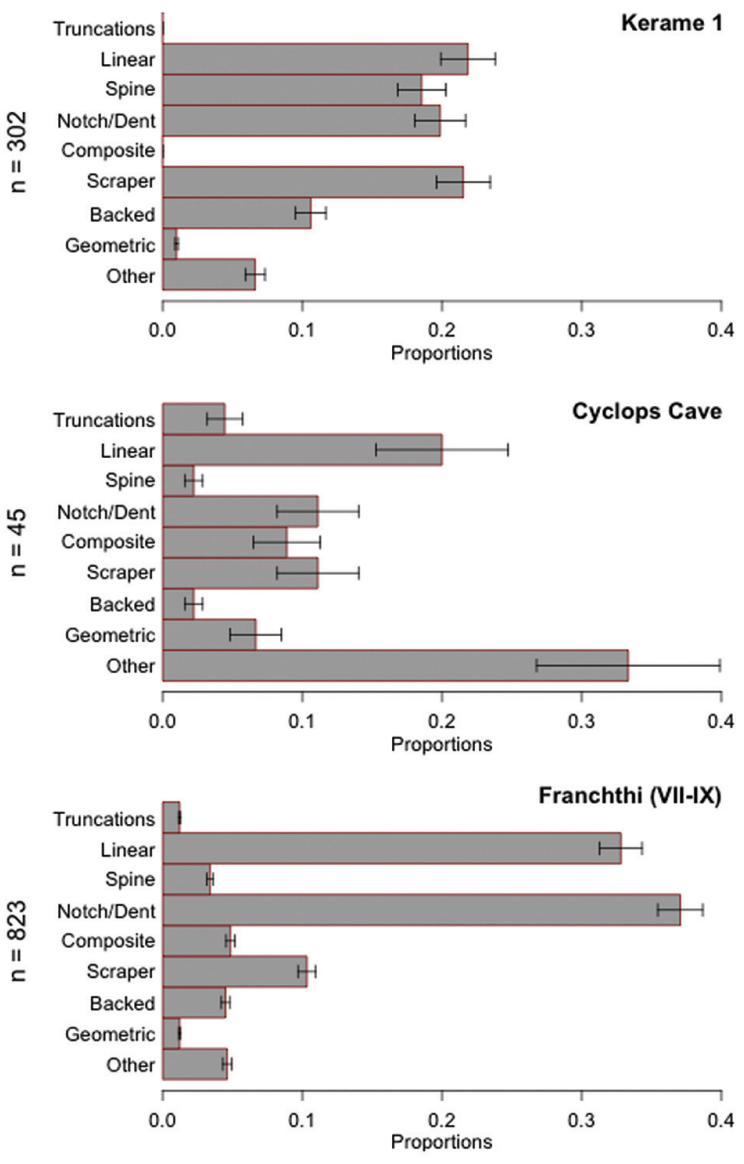

on Crete's subsistence economy, as it remains that their agro-pastoral basis was a package of foreign domesticated and proto-domestic plants and animals that they brought with them (Broodbank, Strasser 1991.236-237; Horwitz 2013; Isaakidou 2008; although Sampson 2008.210, 225 argues for some independent Aegean Island domestication processes).

Where the discovery of a Cretan Mesolithic does change the debate concerns how we view the earliest material culture at Knossos. The first detailed study of Knossian IN chipped stone was undertaken by James Conolly (2008), part of whose work was dedicated to finding the best overseas parallels in order to locate the settlers' homeland(s) and chart their migration routes. The assemblage comprised 394 artefacts, $70 \%$ of which were made from obsidian (in stark contrast to Livari's 1.6\%), plus a wide variety of local raw materials. The assemblage was flake based (approx. 80\%), with the blanks having been percussion-knapped on-site from multiplatform and bipolar cores/pièces esquillées (Conolly 2008.76-77, Fig. 5.1-5.2). There was also a small blade component (11 percussion, two possible pressure), but no associated manufacturing debris. A quarter of the assemblage was modified $(\mathrm{n}=$ 100 ), mostly in the form of non-standardised re- 
touched flakes. For Conolly, the assemblage's closest parallel came from IN Franchthi Cave (phase X), material of perhaps only slightly later date (Perlès 1990.84-85, Tab. 5.3, Fig. 5.5; Perlès et al. 2013). Both were flake-dominated and included small proportions of more technically advanced blade tools ( $2 \%$ at Knossos and 10\% at Franchthi). However, while Perlès (1990.115118) viewed Franchthi's flake component as representing continuity from Mesolithic technical traditions (with the IN the result of 'acculturation' by local (ex-)hunter-gatherers; Perlès et al. 2013.1012), Connolly (2008.85) rejected such an implication for the IN Knossian flake material based on the belief that Crete had no indigenous hunter-gatherer

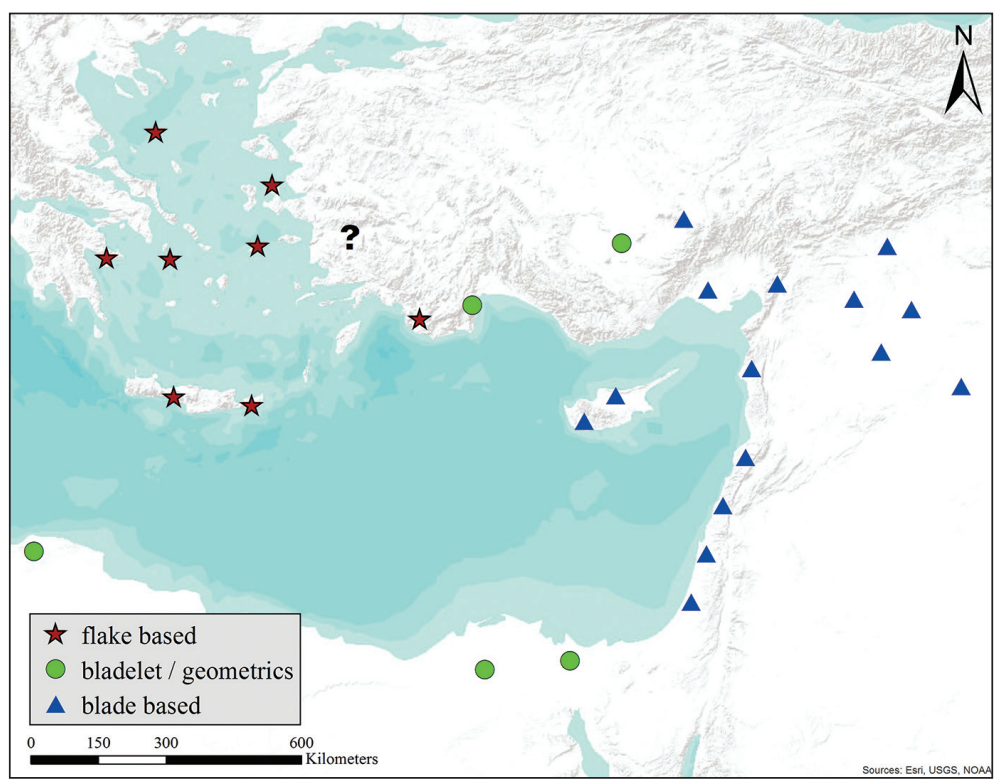

Fig. 9. Lithic traditions of the $9^{\text {th }}-8^{\text {th }}$ millennium BC Eastern Mediterranean. population, i.e. the entire assemblage had to be the product of a foreign tradition. The assemblages' similarity was instead viewed as the result of the communities' comparable environments, which led to the independent development of functionally analogous tool-kits.

Conolly's interpretations have recently been challenged by Malgorzata Kaczanowksa and Janusz $\mathrm{K}$. Kozłowski (2011), whose own study of the Knossian IN material led them to downplay the similarities with IN Franchthi and instead locate Knossos within their early Holocene Aegean Island tradition. In the light of the Livari material, we agree broadly with this position. Ultimately, we believe that the chipped stone from IN Knossos is culturally hybrid. It embodies technical and raw material choices derived from migrant farmer and local hunter-gatherer traditions, which we argue resulted from close population interaction, conceivably through inter-marriage, as allegedly evidenced in the Argolid at Klisoura Cave 1 (Koumouzelis et al. 2003.117-118; although, see Hofmanova et al. 2016; Kilınç et al. 2016 for recent aDNA studies that seemingly argue against forager-farmer admixture). The Livari and Plakias region assemblages now provide the IN Knossos flake-based material, not least the notched/denticulated component, with good Cretan Mesolithic antecedents, while the minority blade component, specifically the pressure blades, provide links to eastern Neolithic traditions. More specifically we suggest that Aceramic Neolithic Çatalhöyük in central Anatolia (Fig. 1) provides not only good parallels for some of the IN Knossian material, but also a conceptual analogy for the site's foundation.

Çatalhöyük's basal levels are dated $c .7100$ BC (Bayliss et al. 2015), with the population's subsistence based on a range of non-local domestic and protodomestic animals and cereals that members of this community likely brought with them from the east, possibly Cappadocia, where agro-pastoralism and sedentism was already established (Hodder 2006.8284 ). The material culture provides further links to this region, with elements of Çatalhöyük's earliest chipped stone forming the westernmost edge of Near Eastern PPNB lithic traditions (Carter 2011. 12). At the same time, the fauna includes significant quantities of wild taxa (Russell, Martin 2005.4446, Fig. 2.3, Tabs. 2.5-2.7), while the chipped stone contains hallmarks of local Epi-Palaeolithic huntergatherer knapping practices with its bladelet technologies, and geometric tool-types (Carter 2011.11). Çatalhöyük's earliest material can thus be conceptualised in terms of cultural hybridity (cf. Bhabha 1995) due to interaction between indigenous hunter-gatherers and non-local farmers; a century later, we seem to witness a similar situation at IN Knossos.

In terms of actual links between IN Knossos and late $8^{\text {th }}$ millennium BC central Anatolian lithic traditions, both Çatalhöyük and nearby Canhasan III (Figs. 1 and 8) produced numerous exhausted bipolar cores or pièces esquillées, plus small quantities of blades, a few of which were pressure flaked (Ataman 1988; Carter et al. 2005.492-495, Fig. 11.8a-8b; Conolly 


\begin{tabular}{|c|c|c|c|c|c|}
\hline Site & Region & Period & $\begin{array}{c}\text { Date } \\
\text { (cal BC) }\end{array}$ & $\begin{array}{c}\text { Obsidian } \\
\%\end{array}$ & $\begin{array}{l}\mathrm{Km} \text { to } \\
\text { Melos }\end{array}$ \\
\hline Livari & Crete & Mesolithic & n.d. & 1.5 & 235 \\
\hline Franchthi Cave (VII) & Argolid & Lower Mesolithic & $8500-8000$ & 0.2 & 135 \\
\hline Franchthi Cave (VIII) & Argolid & Upper Mesolithic & $8000-7500$ & 2.8 & 135 \\
\hline Franchthi Cave (IX) & Argolid & Final Mesolithic & $7200-7000$ & 0.2 & 135 \\
\hline Schisto Cave & Attica & Upper Palaeolithic - Lower Mesolithic & $10000-9300$ & 0.8 & 150 \\
\hline Cyclops Cave, Youra & Sporades & Lower - Upper Mesolithic & $8600-7000$ & 8.4 & 295 \\
\hline Maroulas, Kythnos & Cyclades & Lower Mesolithic & $8800-8600$ & 31.1 & 75 \\
\hline Kerame 1, Ikaria & Dodecanese & Lower Mesolithic & n.d. & 26 & 170 \\
\hline
\end{tabular}

Tab. 4. Mesolithic Aegean sites with obsidian: date, proportion of assemblage, linear distance from source.

2008; Kaczanowksa, Kozłowski 2011). In making these comparisons, one is wary of literalism, as Çatalhöyük is the only well-published central Anatolian site of this date, and differences do exist between their chipped stone assemblages (e.g., the lack of geometrics from Crete); at Knossos this may be partly due to indigenous Cretan influences on migrant Anatolian traditions. To claim Knossian links with central Anatolia is not new, with Arthur Evans (1994. 5) positing parallels in mud-brick construction and aspects of the economy, while part of the modern Cretan population's DNA can be traced back to central and Mediterranean Anatolia through the J2a haplotype, whose appearance on Crete is linked to the spread of farming and Knossos' foundation (King et al. 2008).

\section{The state of play}

While our understanding of the Cretan Mesolithic remains in its infancy, it still forces us to rethink longheld views concerning the foundation of Neolithic Crete. Through reference to Livari and other Aegean island Mesolithic data, one no longer has to invoke the founder principle to explain the idiosyncrasies of Knossian IN material culture, i.e. cultural drift from 'homeland' practices due to the colonists' isolation (Cherry 1985.26-27). For us, the Knossian material represents a hybrid product of farmer and hunter-gatherer traditions, conceivably via group interaction on Crete itself (or through forager-farmer contacts in western Anatolia). Moreover, the presence of Melian obsidian on Mesolithic Crete attests to pre-Neolithic maritime networks connecting Cretans with other islanders (Carter 2016), the ancestral knowledge of which may have then been employed by those early seaborne farmers as they aimed for the island's north coast ( $c f$. Broodbank, Strasser 1991.238-239). The fact we have still to find Early Neolithic sites on the intervening islands between Anatolia and Crete continue to bolster the argument that this was not only a targeted migration, but also a long-range process (Horejs et al. 2015.Fig. 15). In turn, John Cherry's original (1981) claim for a 2000-year gap between the establishment of farming on Crete and the Neolithisation of the smaller Aegean Islands remains largely true (an exception being Uğurlu on Gökçeada/Imbros; Erdoğu 2013). This suggests that the Cretan-Anatolian dual cereal-livestock subsistence basis was incompatible with smaller Aegean landmasses, which tend to lack sizeable tracts of land suitable for arable development $\left(<10-15^{\circ}\right.$ slope). Indeed, the Late Neolithic/5 $5^{\text {th }}$ millennium $\mathrm{BC}$ farming economy that eventually succeeded in the Cyclades was underpinned by sheep/ goat herding and fishing, having filtered out the cereal and cattle component seen on Crete (Broodbank 2000.76-85, Tab. 1).

Other lacunae need to be highlighted. The lack of Mesolithic sites in the southern Dodecanese arguably hampers our claim that Anatolian migrant farmers could have tapped into deep-time knowledge of the sea- and landscapes they were about to encounter via intermediary islanders (though alleged Mesolithic surface finds are documented from Chalki; Sampson 2010.139). That said, with the recent discoveries of late Pleistocene-early Holocene insular sites further to the north on Ikaria and Lemnos (Sampson et al. 2012; Efstratiou et al. 2013), together with the new south-west and western Anatolian evidence ( $\mathrm{Ci}$ lingiroğlu et al. 2016; Takaoğlu et al. 2014), it is arguably only a matter of time before Mesolithic activity is documented on the islands of Rhodes, Karpathos and Kasos (Fig. 1). Another data lacuna we take more seriously is that of later Palaeolithic island occupation. While Livari has some features that might be viewed as transitional Final PalaeolithicLower Mesolithic (proportion of bladelets and inverse retouch), it remains that Crete lacks a well-documented Upper Palaeolithic. This was perhaps to be expected, as most Aegean sites were apparently aban- 
doned during the late Pleistocene-early Holocene transition (Runnels 1995.719, 726-727). Crete's earlier prehistory might thus be viewed as a series of visitations and/or failed colonisations, rather than a continuous occupation from the Middle Pleistocene. Ultimately, Crete's Mesolithic culture can be viewed as the product of yet another migration and part of a broader wave of supra-regional early Holocene maritime activity that Cyprian Broodbank (2006. 208) refers to as the true "birth of Mediterranean seafaring".

The excavation was carried out by Sofianou and Papadatos for the Greek Archaeological Service and Hellenic Ministry of Culture and Sports, with funding also provided by the Institute for Aegean Prehistory (INSTAP) and the National and Kapodistrian University of Athens. INSTAP-East Crete hosted the lithic study, Deanna Aubert and Sean Doyle produced the photographs, Kyle Freund the maps, and Daniel Contreras the graph. Thanks to Deanna Aubert, Çiler Çilingiroğlu, Fanis Mavridis, Marina Milić, Catherine Perlès, Curtis Runnels, Tom Strasser for feedback, the latter also providing permission to reproduce Mihailovic's illustrations of the Damnoni material. We also acknowledge the input of the journal's referees, which helped improve some of the arguments. Carter's work was funded by a Standard Research Grant of the Social Sciences and Humanities Research Council, Canada.

$\therefore$

\section{References}

Ataman K. 1988. The chipped stone assemblage from Can Hasan III: A study in typology, technology and function. Unpublished PhD thesis. Institute of Archaeology. University College London. London.

Bayliss A., Brock F., Farid S., Hodder I., Southon J. and Taylor R. E. 2015. Getting to the bottom of it all: A Bayesian approach to dating the start of Çatalhöyük. Journal of World Prehistory 28: 1-26.

Baird D., Fairbairn A., Martin L. and Middleton C. 2012. The Boncuklu Project: The origins of sedentism, cultivation and herding in Central Anatolia. In M. Özdoğan, N. Basgelen and P. Kuniholm (eds.), The Neolithic in Turkey 3. New excavations and new research: Central Turkey. Arkeoloji ve Sanat Yayınları. Istanbul: 219-244.

Bhabha H. K. 1995. Location of Culture. Routledge. London.

Blitzer H. 2004. Appendix C. The chipped stone and ground stone: Raw material sources, production sites, and finds. In L. V. Watrous, D. Hadzi-Vallianou and H. Blitzer (eds.), The plain of Phaistos. Cycles of social complexity in the Mesara region of Crete. Monumenta Archaeologica 23. Cotsen Institute of Archaeology Publications. Los Angeles: 509-524.

Brandl M. 2010. Chert source areas and provenance studies of chipped stone artifacts in Southeastern Crete. Jahreshefte des Österreichischen Archäologischen Institutes in Wien 79: 324-341.

Branigan K. 1988. Pre-palatial. The foundations of palatial Crete. A survey of Crete in the Early Bronze Age. Adolf M. Hakkert. Amsterdam.
Broodbank C. 2000. An island archaeology of the Early Cyclades. Cambridge University Press. Cambridge.

2006. The origins and early development of Mediterranean maritime activity. Journal of Mediterranean Archaeology 19(2): 199-230.

Broodbank C., Strasser T. 1991. Migrant farmers and the Neolithic colonisation of Crete. Antiquity 65: 233-245.

Carter T. 1998. Reverberations of the "International Spirit": thoughts upon "Cycladica" in the Mesara. In K. Branigan (ed.), Cemetery and society in the Aegean Bronze Age. Sheffield Studies in Aegean Archaeology 1. Sheffield Academic Press. Sheffield: 59-77.

1999. Through a glass darkly: Obsidian and society in the Southern Aegean Early Bronze Age. Unpublished $\mathrm{PhD}$ thesis. Institute of Archaeology. University College London. London.

2007. The chipped stone. In D. C. Haggis, M. S. Mook, T. Carter and L. M. Snyder (eds.), Excavations at Azoria, 2003-2004, Part 2: The Final Neolithic, Late Prepalatial, and Early Iron Age occupation. Hesperia 76(4): 665-716.

2009. L'obsidienne égéenne: caractérisation, utilisation et culture. In M.-H. Moncel, F. Fröhlich (eds.), L'homme et le precieux. Matières minérales précieuses de la préhistoire à aujourd'hui'. British Archaeological Reports IS S1934. Archaeopress. Oxford: 199-212.

2010. Of blades and burials, flakes and funerals: The chipped stone from Moni Odigitria. In A. Vasilakis, K. Branigan (eds.), Moni Odigitria: A Prepalatial Ceme- 
tery and its environs in the Asterousia, Southern Crete. Prehistory Monographs 30. Institute for Aegean Prehistory Academic Press. Philadelphia: 151-169.

2011. A true gift of mother earth: The use and significance of obsidian at Çatalhöyük. Anatolian Studies 61: 1-19.

2015. The chipped stone. In Y. Papadatos, C. Sofianou (eds.), Livari Skiadi. A Minoan Cemetery in Southeast Crete. I. Excavation and finds. Institute for Aegean Prehistory Academic Press. Philadelphia: 113-126.

2016. Obsidian consumption in the Late Pleistocene Early Holocene Aegean: Contextualising new data from Mesolithic Crete. Annual of the British School at Athens 111: 1-22.

Carter T., Conolly J., Spasojević A. 2005. The chipped stone. In I. Hodder (ed.), Changing materialities at Catalhöyük: Reports from the 1995-1999 seasons. McDonald Institute Monographs and BIAA. Cambridge: 221-83; 467-533.

Carter T., Contreras D. A., Doyle S., Mihailović D. D., Moutsiou T. and Skarpelis N. 2014. The Stélida Naxos Archaeological Project: New data on the Mesolithic and Middle Palaeolithic Cyclades. Antiquity Project Gallery 88(341) http://journal.antiquity.ac.uk/projgall/carter 341

Carter T., Contreras D. A., Doyle S., Mihailović D. D. and Skarpelis N. 2016. Early Holocene interaction in the Aegean Islands: Mesolithic chert exploitation at Stélida (Naxos, Greece) in context. In M. Ghilardi (ed.), Géoarchéologie des îles de Méditerrané. Centre National de la Recherche Scientifique éditions. Paris: 275-286.

Carter T., Grant S., Kartal M., Coşkun A. and Özkaya V. 2013. Networks and Neolithisation: Sourcing obsidian from Körtik Tepe (SE Anatolia). Journal of Archaeological Science 40(1): 556-569.

Cauvin J. 2000. The birth of the gods and the origin of agriculture. Cambridge University Press. Cambridge.

Cherry J. F. 1981. Pattern and process in the earliest colonisation of the Mediterranean islands. Proceedings of the Prehistoric Society 47: 41-68.

1985. Islands out of the stream: Isolation and interaction in early East Mediterranean insular prehistory. In A. B. Knapp, T. Stech (eds.), Prehistoric production and exchange. Univesity of California, Los Angeles, Institute of Archaeology. Monograph 25. Los Angeles: 12-29.

Christopoulou A. 1989. The stone tools. In L. Vagnetti, A. Christopoulou and Y. Tzedakis (eds.), Scavi a Nerokourou, Kydonias. Consiglio Nazionale delle Ricerche. Rome: 75-85.
Çilingiroğlu C.., Dinçer B., Uhri A., Gürbıyık C., Baykara İ., Cakırlar C. 2016. New Palaeolithic and Mesolithic sites in the eastern Aegean: the Karaburun Archaeological Survey Project. Antiquity (Project Gallery: http://www. anti quity.ac.uk/projgall/cilingiroglu353).

Conolly J. 2008. The knapped stone technology of the first occupants at Knossos. In V. Isaakidou, P. D. Tomkins (eds.), Escaping the labyrinth: The Cretan Neolithic in context. Oxbow Books. Oxford: 73-89.

Efstratiou N. 2013. Knossos and the beginning of the Neolithic in Greece and the Aegean islands. In N. Efstratiou, A. Karetsou and M. Ntinou (eds.), The Neolithic settlement of Knossos in Crete. New evidence for the early occupation of Crete and the Aegean islands. Institute for Aegean Prehistory. Academic Press. Philadelphia: 201211.

Efstratiou N., Biagi P., Karkanas P. and Starnini E. 2013. A Late Palaeolithic site at Ouriakos (Limnos, Greece) in the Northeastern Aegean. Antiquity 87(335) (Project Gallery: http://www.antiquity.ac.uk/projgall/efstratiou335/).

Erdoğu B. 2013. Uyyyurlu, a Neolithic settlement on the Aegean island of Gökçeada. In M. Özdoğan, N. Başgelen and P. Kuniholm (eds.), The Neolithic in Turkey 5. New excavations and new research: Northwestern Turkey and Istanbul. Arkeoloji ve Sanat Yayınları. Istanbul: 1-33.

Evans J. D. 1994. The early millennia: Continuity and change in a farming settlement. In D. Evely, H. HughesBrock and N. Momigliano (eds.), Knossos a labyrinth of history: Papers presented in honour of Sinclair Hood. British School at Athens. London: 1-20.

Galanidou N. 2011. Mesolithic cave use in Greece and the mosaic of human communities. Journal of Mediterranean Archaeology 24(2): 219-242.

Hodder I. 2006. Catalhöyük: the leopard's tale, revealing the mysteries of Turkey's ancient 'town'. Thames and Hudson. London.

Hofmanová Z. and 37 co-authors. 2016. Early farmers from across Europe directly descended from Neolithic Aegeans. Proceedings of the National Academy of Sciences USA 113(25): 6886-6891.

Horejs B., Milić B., Ostmann F., Thanheiser U., Weninger B. and Galik A. 2015. The Aegean in the early $7^{\text {th }}$ Millennium BC: Maritime networks and colonization. Journal of World Prehistory 28: 289-330.

Horwitz L. K. 2013. The earliest settlement on Crete: An archaeozoological perspective. In N. Efstratiou, A. Karetsou and M. Ntinou (eds.), The Neolithic settlement of Knossos in Crete. New evidence for the early occupa- 
tion of Crete and the Aegean islands. Institute for Aegean Prehistory Academic Press. Philadelphia: 171-192.

Isaakidou V. 2008. The fauna and economy of Neolithic Knossos' revisited. In V. Isaakidou, P. D. Tomkins (eds.), Escaping the labyrinth: The Cretan Neolithic in context. Oxbow Books. Oxford: 90-114.

Kaczanowksa M., Kozłowski J. K. 2011. Lithic industry from the Aceramic levels at Knossos (Crete, Greece): An alternative approach. Eurasian Prehistory 8(1-2): 67-87.

2014. The Aegean Mesolithic: Material culture, chronology and networks of contact. Eurasian Prehistory 11(1-2): 31-61.

Kartal M. 2009. Konar göçerlikten yerleşik yaşama geçiş Epi-Paleolitik dönem: Türkiye'de son avcr-toplayıctlar. Arkeoloji ve Sanat Yayınları. Istanbul.

Kılınç G. M. and 26 co-authors. 2016. The demographic development of the first farmers in Anatolia. Current Biology 26: 1-8.

King R., Özcan S., Carter T., Kalfoglu E., Atasoy S., Triantiphyllidis K., Kouvatsi A., Lin A., Chow C., Zhivotovsky L., Tsopanomichalou M. and Underhill P. 2008. Differential Y-Chromosome Anatolian influences on the Greek and Cretan Neolithic. Annals of Human Genetics 72: 205214.

Knapp A. B. 2013. The archaeology of Cyprus from earliest prehistory through the Bronze Age. Cambridge University Press. Cambridge.

Kotsakis K. 2003. From the Neolithic side: The Mesolithic/Neolithic interface in Greece. In N. Galanidou, C. Perlès (eds.), The Greek Mesolithic. Problems and perspectives. British School at Athens Studies 10. London: 217221.

Koumouzelis M., Kozłowski J. K. and Ginter B. 2003. Mesolithic finds from Cave 1 in the Klisoura Gorge, Argolid. In N. Galanidou, C. Perlès (eds.), The Greek Mesolithic. Problems and perspectives. British School at Athens Studies 10. Nottingham: 113-122.

Martinez L., Underhill P. A., Zhivotovsky L. A., Gayden T., Moschonas N. K., Chow C.-E. T., Conti S., Mamolini E., Cavalli-Sforza L. L. and Herrera R. J. 2007. Paleolithic Y-haplogroup heritage predominates in a Cretan highland plateau. European Journal of Human Genetics 15: 1-9.

Midant-Reynes B. 2000. The prehistory of Egypt. Blackwell. Oxford.

Papadatos Y., Sofianou C. 2015. Livari Skiadi. A Minoan cemetery in Southeast Crete. I. Excavation and finds. Institute for Aegean Prehistory Academic Press. Philadelphia.
Perlès C. 1987. Les industries lithiques taillées de Franchthi (Argolide, Grèce) I. Présentation générale et industries Paléolithiques. Excavations at the Franchthi Cave, Fascicle 3. Indiana University Press. Bloomington, Indianapolis.

1990. Les industries lithiques taillées de Franchthi (Argolide, Grèce) II. Les industries du Mésolithique et du Néolithique Initial. Excavations at the Franchthi Cave, Fascicle 5. Indiana University Press. Bloomington, Indianapolis.

2001. The early Neolithic in Greece. Cambridge University Press. Cambridge.

Perlès C., Quiles A. and Valladas H. 2013. Early seventh millennium AMS dates from domestic seeds in the Initial Neolithic at Franchthi Cave. Antiquity 87: 1001-1015.

Pinhasi R., Fort J. and Ammerman A. J. 2005. Tracing the origin and spread of agriculture in Europe. Public Library of Science Biology 3(12): 2220-2228.

Rahmani N. 2004. Technological and cultural change amongst the last hunter-gatherers of the Mahgreb: The Capsian (10,000-6000 BP). Journal of World Prehistory 18(1): 57-105.

Renfrew C., Aspinall A. 1990. Aegean obsidian and Franchthi Cave. In T. W. Jacobsen (ed.), Excavations at Franchthi Cave, Greece. Fascicle 5. Indiana University Press. Bloomington: 257-279.

Runnels C. 1995. Review of Aegean prehistory IV: The stone age of Greece from the Palaeolithic to the advent of the Neolithic. American Journal of Archaeology 99(4): 699- 728 .

Runnels C. N. 2009. Mesolithic sites and surveys in Greece: A case study from the Southern Argolid. Journal of Mediterranean Archaeology 22(1): 57-73.

Russell N., Martin L. 2005. The Çatalhöyük mammal remains. In I. Hodder (ed.), Inhabiting Çatalhöyük: Reports from the 1995-1999 seasons. McDonald Institute Monographs and BIAA. Cambridge: 33-98.

Sampson A. 2008. The Cave of the Cyclops: Mesolithic and Neolithic networks in the Northern Aegean, Greece. Institute for Aegean Prehistory. Academic Press. Philadelphia.

2010. Mesolithic Greece. Ion. Athens.

2015. An extended Mesolithic settlement in Naxos. $M e$ diterranean Archaeology and Archaeometry 16(1): 269-271.

Sampson A., Kaczanowksa M. and Kozłowski J. K. 2010. The prehistory of the island of Kythnos (Cyclades, Gre- 
ece) and the Mesolithic settlement at Maroulas. The Polish Academy of Arts and Sciences. The University of the Aegean. Kraków.

2012. Mesolithic occupations and environments on the island of Ikaria, Aegean, Greece. Folia Quaternaria 80: 5-40.

Shea J. J. 2013. Stone tools in the Paleolithic and Neolithic of the Near East: A guide. Cambridge University Press. Cambridge.

Strasser T. 1996. Soils and settlements on Neolithic Crete. In D. Reese (ed.), The Pleistocene and Holocene fauna of Crete and its first settlers. Monographs in World Archaeology No. 28. Prehistory Press. Madison: 317-336.

Strasser T., Panagopoulou E., Runnels C., Murray P., Thompson N., Karkanas P., McCoy F. and Wegmann K. 2010. Stone Age seafaring in the Mediterranean: Evidence from the Plakias region for Lower Palaeolithic and Mesolithic habitation of Crete. Hesperia 79: 145-190.
Strasser T. F., Runnels C., Wegmann K., Panagopoulou E., McCoy F., DiGregorio C., Karkanas, P. and Thompson N. 2011. Dating Palaeolithic sites in Southwestern Crete, Greece. Journal of Quaternary Science 26(5): 553-560.

Strasser T. Panagopoulou E., Karkanas P., DiGregorio C., Clinton M., Thompson N., Kapranos E. and Murray S. 2015. The excavation at Mesolithic Damnoni in the Agios Vassilios region: A new chronological / cultural period on Crete. In P. Karanastasi, A. Tzigounaki and C. Tsigonaki (eds.), Archaeological work in Crete 3. Philosophical School of the University of Crete and the Archaeological Ephoreia of Rethymnon. Rethymnon: 271-80.

Tixier J. 1984. Le Débitage par Pression. Préhistoire de la pierre taillée 2: Economie du débitage laminare: Technologie et expérimentation. Centre National de la Recherche Scientifique. Paris.

Takaoğlu T., Korkut T., Erdoğu B. and Işın G. 2014. Archaeological evidence for $9^{\text {th }}$ and $8^{\text {th }}$ millennia BC at Girmeler Cave near Tlos in SW Turkey. Documenta Praehistorica 41: 111-118. 
